Article

\title{
Streets as Public Spaces: Lessons from Street Vending in Ahmedabad, India
}

\author{
Prithvi Deore * and Saumya Lathia
}

Sol Price School of Public Policy, University of Southern California, Los Angeles, USA; E-Mails: pdeore@usc.edu (P.D.), slathia@usc.edu (S.L.)

* Corresponding author

Submitted: 10 March 2019 | Accepted: 3 June 2019 | Published: 30 June 2019

\begin{abstract}
Public spaces go beyond the typical definition of being an open space. They reflect the diversity and vibrancy of the urban fabric and hold the power to create memories. Among all public spaces, streets emerge as the most public. Streets are engines of economic activities, social hubs, and platforms for civic engagement. They break socio-economic divides and foster social cohesion. Planning, designing, and managing better public spaces have become important global discussions. Sustainable Development Goals ( 8 and 11) and the New Urban Agenda emphasize the significance of inclusive and sustainable economy and safe, accessible and quality public spaces for all. The proposed article uses the case of street vending to understand the manifestation of these goals in an Indian context by assessing street vendors' role in Ahmedabad's urban fabric through extensive spatial analysis of 4,000 vendors at four different time points of the day, perception studies of their clientele disaggregated by gender, income and age, and their relationship with surrounding land-use and street hierarchy. It showcases how street vendors make the streets more vibrant by increasing activities, safer through ensuring inflow of people, and inclusive in its true sense by allowing people from different backgrounds to participate in the exchange of goods and services. It further argues that street vendors are vital elements of more equitable and exciting streets and public space.
\end{abstract}

\section{Keywords}

equity; India; public spaces; safety; streets; street vending

Issue

This article is part of the issue "Public Space in the New Urban Agenda: Research into Implementation", edited by Michael W. Mehaffy (KTH Royal Institute of Technology, Sweden), Tigran Haas (KTH Royal Institute of Technology, Sweden), and Peter Elmlund (Axel and Margaret Ax:son Johnson Foundation, Sweden).

(C) 2019 by the authors; licensee Cogitatio (Lisbon, Portugal). This article is licensed under a Creative Commons Attribution 4.0 International License (CC BY).

\section{Introduction}

Rapid urbanization and population growth have initiated numerous urban planning, design, and management discussions worldwide. Many cities are struggling with lack of affordable housing, basic services, infrastructure, open spaces, increased vehicular traffic, air pollution and environmental risks. Thus, Sustainable Development Goals (SDGs) (especially 11) and the New Urban Agenda promotes cities and urban spaces that are more inclusive, safe, resilient and sustainable.
Many scholar and urbanists believe public spaces, historically known as open spaces, are the true reflection of the city's richness and diversity (Jacobs, 2002), "the window into a city's soul" (Zukin, 1995), "physical representation of democracy" (Thalis \& Cantrill, n.d.) and the "measure of a city's greatness" (New Urbanism, n.d.). Across the globe, public spaces are known to be multifunctional areas that foster social interaction and inclusion, promote human health and well-being, boost cultural and civic expression, and support economic exchange. 
Streets are the most "public": they are responsive, accessible, diverse, democratic and multipurpose (Carr, 1992). In all civilizations, streets have been the most widely used public space, with neighborhood commercial streets and bazaars being the most popular (Brower, 1996). Studies in contemporary context highlight that development pressure, increasing space demands, fastmoving vehicles, and hostile social and political environments have brought a "conceptual and physical shift" in urban public spaces, making the streets a highly contested space (Jain \& Moraglio, 2014). Indian streets traditionally known to balance the need to support livelihoods with the need to manage space for other activities are struggling to maintain this balance much like other cities in the global South by often prioritizing automobiles over other users (Roever \& Skinner, 2016). This has given rise to major street reclamation movements like "livable streets" and "complete streets" around the world (Mboup, Warah, \& United Nations Human Settlements Programme, 2013). Recent literature emphasizes that this contested nature of streets constantly "criminalizes" and excludes the urban poor including street vendors, porters, traders, etc. through urban policies and government practices. SDGs $(3,8$ and 11) and the New Urban Agenda show deep commitment to protect and include these groups while envisioning public spaces by all.

Given this background, this article evaluates the role of street vending in creating "good" public spaces. Following the introduction, this article presents a short review of good public space theories and the status of street vending globally, with an emphasis on the study area. It later discusses the case of Ahmedabad's street vendors, how they respond to land-use and street hierarchy and the perception of their clientele on street vending in a contested space.

\section{Public Spaces and Street Vending}

\subsection{Attributes of a "Good" Public Space}

Public spaces add economic, social, and environmental value to cities, and numerous studies have attempted to measure the value of public spaces and evaluate the components of successful public spaces (Kim, 2015). Jan Gehl (2011) described how the physical form and activities create a street scene. Determined by their physical space and environment, activities can be classified as necessary, optional, and social activities. Necessary activities are the mandatory activities formed around daily life such as going to work, shopping, or attending school. These activities occur year-round, and are barely affected by the physical environment. Optional activities are seasonal activities, mostly recreational in nature, and driven by a pleasant outside environment. Examples of optional activities are taking a leisurely walk, sitting in a park, and sunbathing. Social activities however rely on different degrees of social interaction in a space. These activities include a casual greeting between acquaintances in a residential area, or "passive contacts" between strangers in public areas. As per Gehl, "good" public spaces allow for all three types of activities. However, Brower (1996) suggests that land-use governs activity generation, and highlights how good mixeduse environments often have liveliness and a diversity of activities.

Vikas Mehta's (2007) Good Public Space Index is broadly divided into six measures: intensity of use, intensity of social use, people's duration of stay, temporal diversity of use, and variety of use. These indicators are calculated using variables such as the number of people engaged in groups, time spent, duration of stay, and number of activities in the space. The toolkit highlights how the diversity of users is an important measure, but one often difficult to capture.

Historically, public spaces were extensions of other spaces such as living spaces, religious spaces, and market spaces. Thus the "local distinctiveness" evaluated for a place's uniqueness if measured by character, continuity, sense of space, quality of public realm, legibility, and adaptability (Sasidharan \& Prosperi, 2012).

Placemaking is changing the course of public spaces. Project for Public Spaces' (PPS, n.d.) Place Diagram divides the attributes of a successful space into Uses and Activities, Comfort and Image, Sociability and Access and Linkages. These attributes are further divided into intangibles and measurements that are qualitative, quantitative, or intuitive in nature. These models and analysis from previous literatures inform the evaluation criteria for a "good" public space in this study.

\subsection{Street Vending: Global Status and Common Perceptions}

Street vendors account for a considerable share of urban employment and revenue generation. Studies by WIEGO's StreetNet show that street vendors constitute 13-24 percent of workers in African cities, 11 percent in Chinese cities, 9 percent in Latin-American cities and 4-6.5 percent in Indian cities. A large share of street vendors are women, including 51 percent in SubSaharan Africa (Herrera, Kuépié, Nordman, Oudin, \& Roubaud, 2012).

Most government institutions recognize street vendors as an integral part of urban economies globally. Per the Supreme Court of India, street vendors "considerably add to the comfort and convenience of the general public, by making available ordinary articles of everyday use for a comparatively lesser price." They are also self-employed, support other smaller businesses, employ others to package, transport or sell their goods and generate significant revenue in cities (Herrera et al., 2012). They decrease urban food insecurity by providing for the urban poor, and make goods and services convenient for other classes, particularly the middle class (Roever \& Skinner, 2016). In addition, they make streets 
more interesting and vibrant by adding color and offering diverse experiences. They make public spaces safer by acting as "informal surveillance," popularly known as "eyes on the street." Street vendors are key elements of a thriving urban economy and space (Benítez, Grice, \& Harvey, 2018).

Despite this, street vendors are central to the debate of space, and are subjected to constant hostile negotiations with all urban pressure groups, such as the local body, police, clientele, private developers and realestate agents, shop-owners, affluent resident organizations, or vehicle-owners (Ray \& Mishra, 2011). Most urban pressure groups view street vendors as an "eye-sore" in their ambitious "world-class" city (Anjaria, 2006). This perception is rooted in the colonial mentality of urban planning, design, and governance. Studies of cities across the globe show that street vendors maintain a predominately strained relationship with the State. In Indian cities, the Urban Local Bodies and the Police often perceive street vendors as "illegal," "encroachers" and "tax evaders," who undeservingly occupy a city's prime public spaces and streets (Salès, 2018). Similarly, affluent resident organizations and business associations believe street vendors are the flag-bearers of "chaos" and "nuisance" in urban spaces and must thus be immediately removed from city street and public spaces (Anjaria, 2006). These groups further argue that street vendors belonging to 'lower' caste, class, minority religions, and different national origins break the homogeneity of their neighborhoods (Salès, 2018). Real-estate developers meanwhile believe that the presence of street vendors indicates an "impoverished" and "dirty" neighborhood, and depresses the real estate values of their property (Joshi, 2018). On the contrary, most shop-owners, especially in western India, believe that street vendors guard their shops and attract more customers. Thus, along many commercial streets, formal shop-owners, especially jewelry shop owners, rent out their shop extensions to street vendors (Roever \& Skinner, 2016). They promise to protect street vendors from eviction and to provide access to water, sanitation, and electricity. Studies show that shop-owners often have long and strong relationships with the vendors working outside their shops (Roever \& Skinner, 2016). Despite this possibility of a symbiotic relationship, some shop-keepers believe vendors are encroaching and competing against them and do not want the street vendors to conduct business in public spaces. These common perceptions interplay to create hostile environments for street vendors. As a result, an overwhelming majority of street vendors pay regular extortion money and bribes, or Hafta, to government officials and the police (Mahadevia, Mishra, Joseph, \& Das, 2016). They pay protection money to local leaders who promise to negotiate with other pressure groups on their behalf or pay rents to shop-owners for the same protections. Many street vendors will negotiate with private security officials of near-by commercial or institutional properties to use their water stations and toilets. Ample evidence on current urban policies and administration practices show how street vendors are subjected to large-scale evictions, displacements, and structural violence across the world (Herrera et al., 2012; Roever, 2014; Roever \& Skinner, 2016), causing anxiety and fear for the vendors and their families.

\subsubsection{Street Vending in Ahmedabad}

With a population of 6.35 million (Census, 2011) and an urban area of 466 square $\mathrm{km}$, Ahmedabad is the commercial and cultural center of the state of Gujarat. Currently, Gujarat is considered India's "model state" for economic development and freedom by development driven school of thought (Bhaskar, 2019). This makes Ahmedabad the working laboratory to implement innovative urban planning, governance, and administrative solutions (Mahadevia et al., 2013). Once known as the "Manchester of India," the city experienced a steep decline in industrial growth during the 1980s, leaving over 67,000 textile mill workers unemployed. This crisis in the formal sector employment led to a boom in the city's informal sector (Mahadevia, Desai, \& Vyas, 2014; Ray, 2010). Street vending is one of the most visible forms of the informal economy, and constitutes roughly 23 percent of the city's informal sector (Mahadevia et al., 2013). Ahmedabad has a population of about 100,000 street vendors, which is the fourth largest in India.

There is a strong culture of celebrating streets in Ahmedabad. This 'kaleidoscope of color and culture' constitutes famous bazaars like Law garden's handicraft market, Jamalpur's flower-market, jewelry markets in Rani No Hajiro, vintage markets of Ravivari, and numerous "khau-gallis" or street food markets like Manek Chowk. The markets in the city reclaim the streets for all and offer an "alternate nightlife."

Ahmedabad's growing population and increasing vehicle ownership (from 1.6 million in 2012 to 3.6 million in 2018; Statista, 2018) puts immense pressure on the city's physical and social infrastructure. While the city's historically vital public spaces such as its bridges, street bazaars, sidewalks, cross-roads, chowks or public squares, and roundabouts are constantly contested (Shah, 2009), the city has only 2 percent of its total land area dedicated to open space, or roughly 1.1 square meters per capita, compared to the universal standard of 8-10 square meters (Mahadevia, Bhatia, Abhilasha, \& Patel, 2017). This creates an acute shortage of formal as well as informal public spaces.

Since the early 2000s, Ahmedabad's hunger to become a "world-class city" has produced an urban development model fueled by the aspiration of the city's upper class. Like most cities in the global south, Ahmedabad's world-class city vision has no space for the city's urban poor (Benítez et al., 2018; Mahadevia, Vyas, \& Mishra, 2014). Several large-scale urban renewal projects, aimed at improving the city's image, evicted thousands of poor households and gravely impacted their livelihoods (Desai, 
2014; Roever, 2014). A 2016 study by Roever and Skinner analyzed the challenges faced by street vendors and concluded that Ahmedabad has one of the highest workplace insecurity, incidences of evictions, and harassment rates among cities in the global south.

Ahmedabad Municipal Corporation's (AMC) Street Vendor's Scheme 2010 is the poster child of exclusionary local policies that thrive on loopholes in legislation to further exploit the urban poor instead of protecting them. The struggle for street vendors' rights in Ahmedabad began in the early 1970s. Self-Employed Women's Association (SEWA), a non-profit advocacy group, filed a petition in 1974 against the State of Gujarat, AMC and other related bodies responsible for exploiting and harassing the street vendors in Manek Chowk (Mahadevia \& Vyas, 2012). To advocate for street vendors rights and protection, SEWA petitioned for allocated spaces, licenses, and basic services for vendors. Moved by SEWA's appeal and arguments, the High Court ordered AMC to provide $4 \mathrm{ft}$ by $4 \mathrm{ft}$ spaces, licensing, sanitation, electricity, shade, and access for all vendors in Manek Chowk. Despite this, AMC continued mistreating street vendors, and refused to comply with the Court's order (Mahadevia \& Vyas, 2012). In light of increased and frequent harassment for nearly a decade, SEWA filed another petition 1987 to implement the Court's order in Manek Chowk and added six other prominent city level markets to the petition. While SEWA fought the case in Court for two decades, street vendors faced evictions, confiscation of goods, and exploitation. In 2006, SEWA filled a Public Interest Litigation (PIL) to implement the National Policy on Urban Street Vendors (NPUSV) in 2004, which is a national policy aimed at protecting the rights of street vendors. Rather than implement the NPUSV, the AMC drafted another policy that overlooked the concept of "Natural Markets," a phenomenon in which vendors locate themselves at places with high economic opportunity, often created by high demand, accessibility, and visibility. The AMC's 2010 scheme aimed to regulate vending through the provision of three vending zones: Green Zone, where vending would be permitted in residential areas on roads less than 15 meters wide from 7 am to 9 am; Amber Zone, where vending would be permitted in commercial areas on roads more than 15 meters wide from 6 am to 9 am and $6 \mathrm{pm}$ to $9 \mathrm{pm}$; restricted vending on institutional area from 7 am to $7 \mathrm{pm}$ and in the heritage area, provided that the vending occured 200 meters away from any heritage site; and Red Zone, where no vending is permitted on roads more than 30 meters wide or with heavy traffic, nor within 200 meters radius of heritage and major commercial areas. Implementing this scheme would adversely impact 129 out of the 174 natural markets, resulting in large-scale displacement, and the loss of economic opportunity and growth (Mahadevia \& Vyas, 2012).

In 2014, India passed a national legislation called The Street Vendors (Protection Of Livelihood And Regulation Of Street Vending) Act to mainstream street vendors and protect their rights. A salient feature of the Act is that no ULB must evict street vendors from their natural markets without allocating space or issuing a license to conduct their business. Unsurprisingly, the State of Gujarat has the lowest compliance rate among all states in India (John \& Sharma, 2018). Major cities in Gujarat have initiated mass-encroachment and eviction drives to remove street vendors from the city streets. These drives have collectively displaced several thousand street vendors, which adversely impact their economic stability and the city's revenue generation, and have sucked the life out of Gujarat's public realm. Between 2009 and 2012, over 4,000 street vendors in Ahmedabad were displaced to make space for large-scale infrastructure and development projects. In August 2018, another 5,000 street vendors were evicted from the streets of Ahmedabad (John \& Sharma, 2018). Some sources show that the AMC removed over 19,500 structures to "free up" 48,000 sqm of land area (John \& Sharma, 2018).

\section{Methodology}

The study is based in Ahmedabad City's West Zone, which is one of six administrative zones in the AMC. West Zone has an area of 56.53 square $\mathrm{km}$, or 12 percent of the city's area, a population of 732,336 , or 11 percent of the city and 24 percent of total street vendors population (Skinner, Orleans, \& Harvey, 2018). West Zone has the most diverse socioeconomic characteristics and landuses, which minimizes any potential biases. It also has the highest percentage of "formal" public space allocation in the city.

There are two predominate types of vending practiced in Ahmedabad: traditional, which occurs in the Walled City, and contemporary, which occurs in the city's western side. Studies usually discuss the socio-economic, legislative, and design challenges of "traditional vending," and seldom look at the impact of contemporary street vending on the city's public realm. This study aims to bridge that gap by providing a detailed account of the West Zone of Ahmedabad. The West Zone is distributed into ten wards, which are the smallest urban administrative unit. The study involved two rounds of data collection through mixed research methods.

Round 1 was the preliminary round. The aim of this round was to understand basic characteristics of street vending: location patterns, agglomeration types, nature, typology, duration and frequency of vending, good and services sold, as well as the personal characteristic of street vendors. Rigorous field visits were conducted between May 2014 and July 2014, and the data was collected on both weekdays and weekends during multiple time-slots throughout the day. 4,000 street vendors were marked in this Point-in-Time (PIT) survey, along with their characteristics through the observations mentioned in Figures 1 and 2. The observations were geocoded and cataloged in ArcGIS for further spatial analysis. This dataset was then analyzed with the city's street hierarchy, sidewalks, and canopy tree cover. 


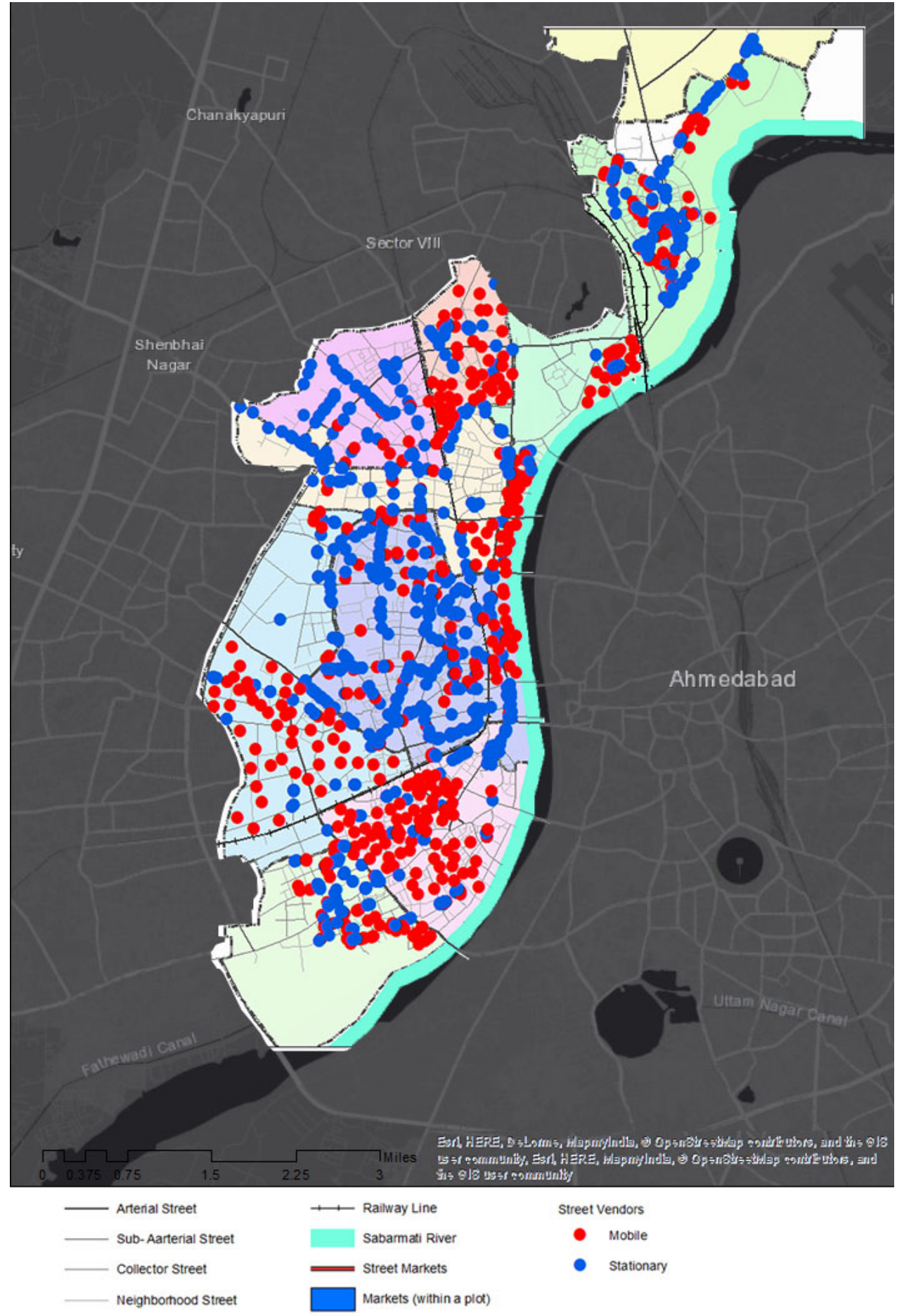

Figure 1. Nature of street vending: mobile and stationary. Source: field work.

Round 2 was the detailed assessment, which constituted of five cases selected for a detailed assessment based on a combination of the results of Round 1, the diversity of land-use, and vendor agglomeration. This indepth assessment included observing the relationship between street type, land use and agglomeration of vendors, footfall, and clientele characteristics. Infrastructure provision such as public toilets, water stations, adequate lighting, and waste management were also noted. The clientele at all five locations were surveyed to understand their experiences of the space and perception of street vending. A total of 100 clients, or 20 at each location, were surveyed face-to-face through random sampling. The semi-structured questionnaire aimed at understanding what brings them to this space, their frequency of usage, how they spend their time in the space, their perceptions of the space, and their perceptions of street vending. 


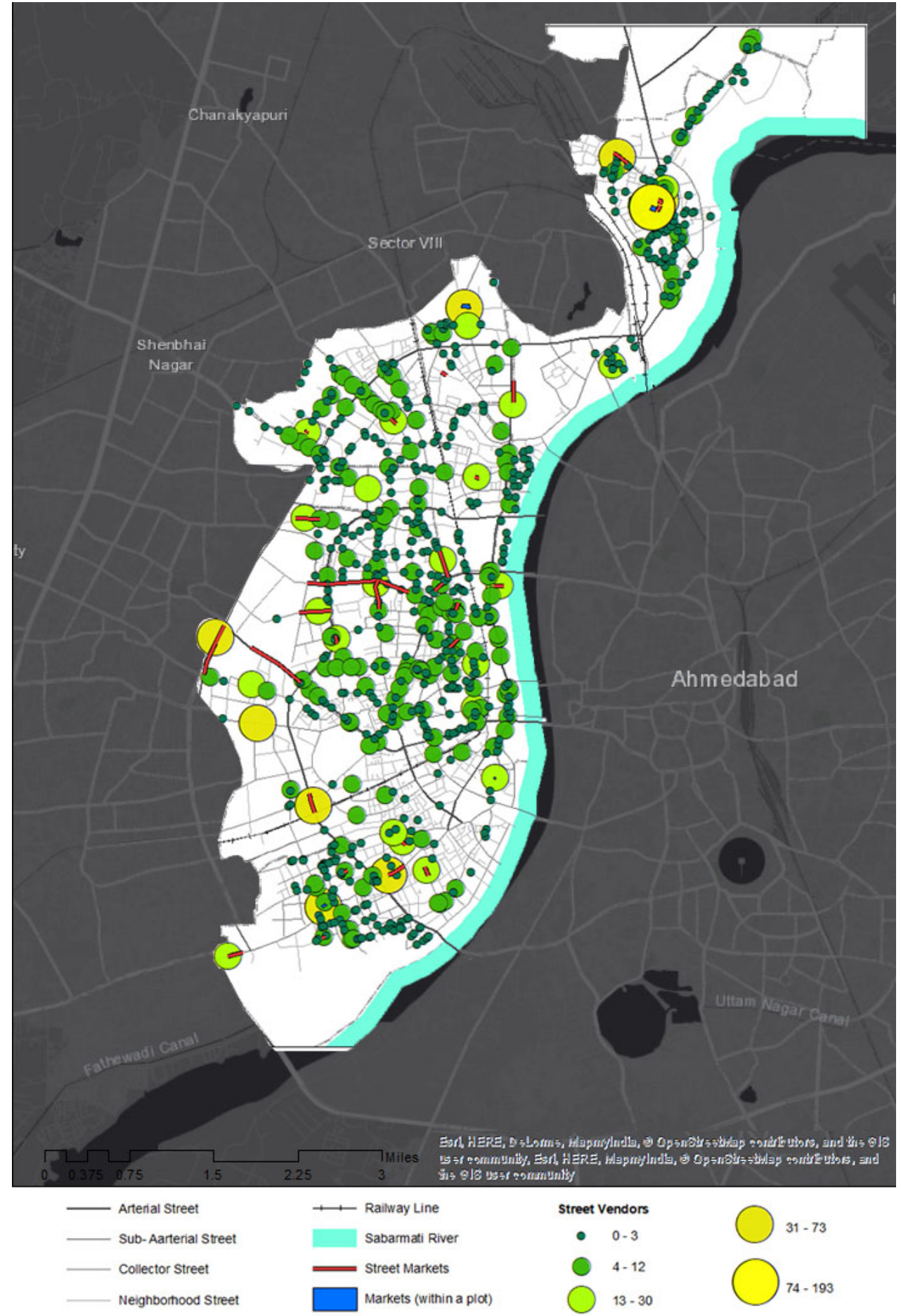

Figure 2. Street and cluster market map. Source: field work in Round 1.

\section{Key Research Findings}

The literature helps us dissect the study observations into five broad attributes of a "good" public space: vibrancy, access, safety, infrastructure, and equity. The following sections elaborate on each of these parameters using a specific case study. All these cases are used to highlight the role of street vendors in making streets more public. All cases look at land uses, street vendor's merchandise type, canopy cover, street type, and space use, along with other aspects, as displayed in Figures 3 to 7. Perception study conducted at each case study site was used to understand the contribution of street vendors to space even further.

\subsection{Vibrancy}

As mentioned previously, vibrancy is identified as an essential indicator of a "good" public space. Some qualitative and quantitative variables of vibrancy include activ- 


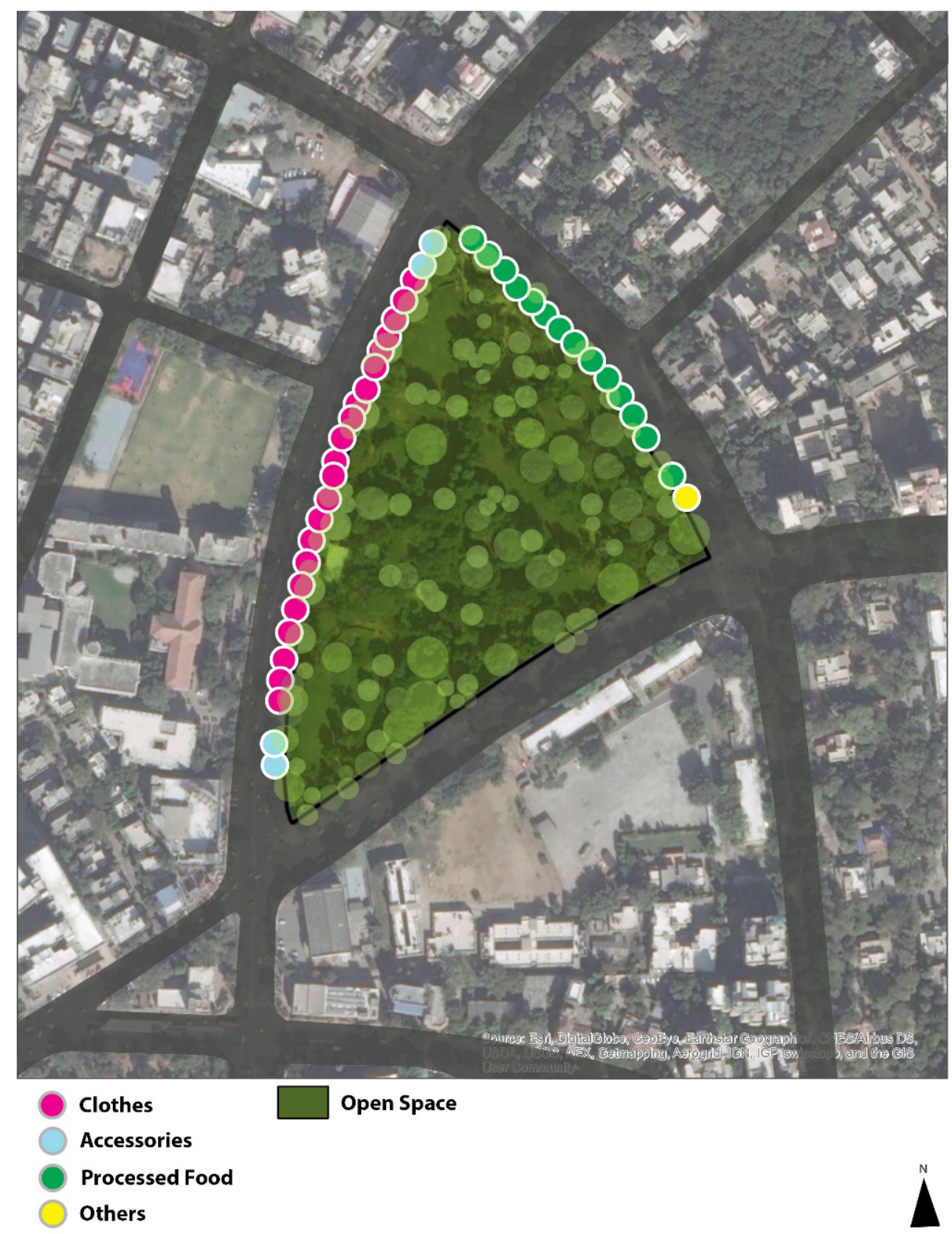

Figure 3. Street vendors around Vasna local garden. Source: Field work.

ity generation, duration of stay, diversity of activity, and footfall. All five case studies in Ahmedabad highlight how the presence of street vendors make public spaces more vibrant and engaging. To understand these variables in greater detail, this study utilized the case of a neighborhood park in Vasna, Ahmedabad.

\subsubsection{Vasna's Neighborhood Park}

Vasna, one of the oldest wards in Ahmedabad, is predominantly a residential ward with a population of 100,000 . Vasna is a classic illustration of the dichotomy in Indian cities. High-end and gated residential communities compose over 50 percent of the ward's land area, however roughly 30 percent of Vasna's population lives in slum settlements on 10 percent of the total land area. 23 percent of Vasna's low-lying, flood-prone land is vacant, leaving only 2 to 3 percent of the ward's land available for dedicated green or open space. The shortage of "formal" public spaces makes neighborhood parks such as this vital for the community's social, mental, and physical well-being.

This park was selected mainly for its location, scale, and nature. It is located amidst a mix of different building typologies, land-uses, and income groups. Compared to the open spaces located near high-end residential communities, this park is smaller in size and has fewer amenities. The park has rigid hours of operation and closes 


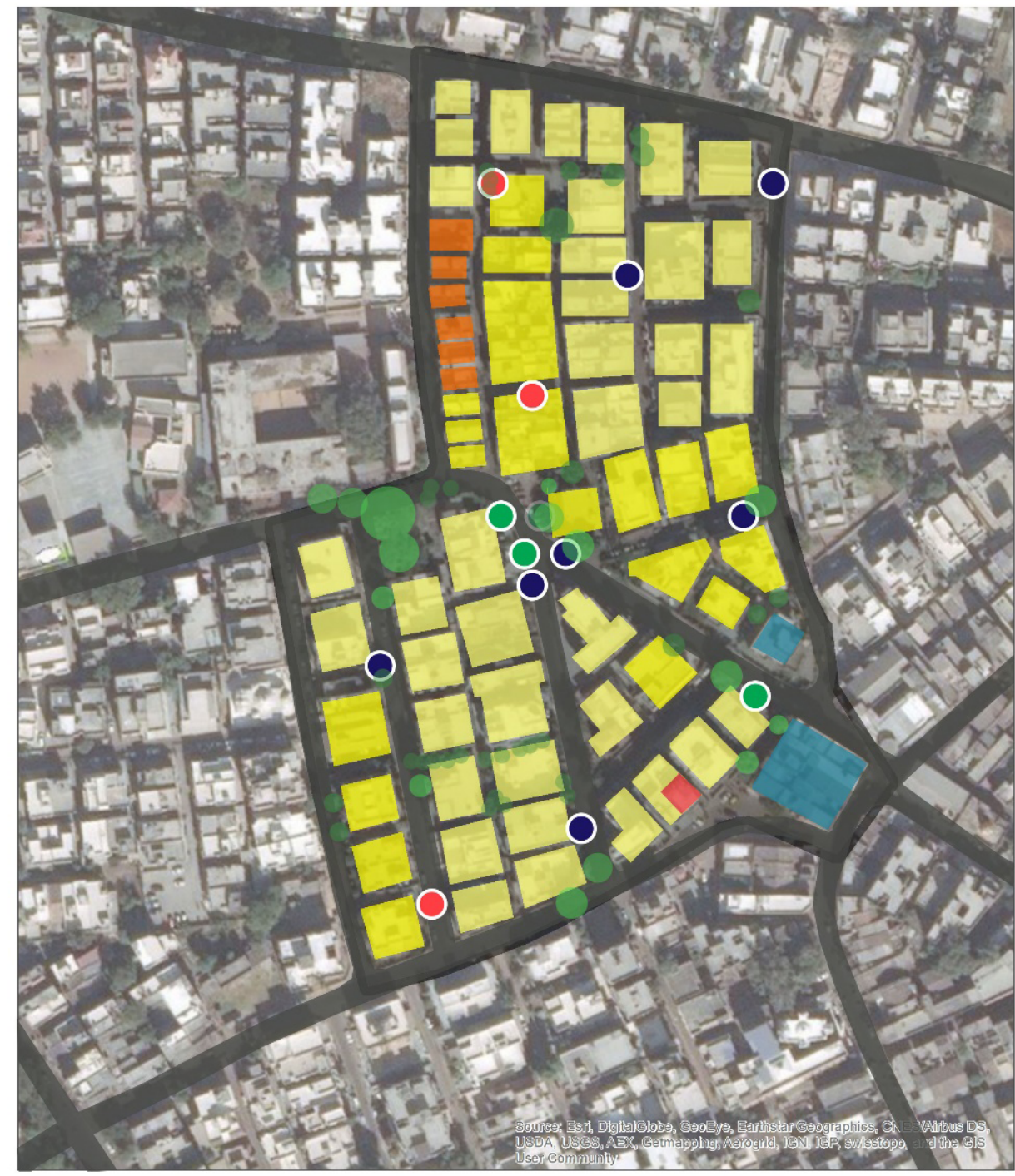

Processed food

Raw food

Services
Residential (Single-family) Residential (Multi-family)

Commercial

Institutional
Mixed-use

$\stackrel{\Lambda}{N}$

Figure 4. Street vendors in and around residential area in Sabarmati ward. Source: Field work.

around late evenings. The vendors are clustered on the sidewalk along the park. Over 50 percent of vendors sell processed food, 30 percent sell fruits and vegetables, and around 20 percent sell clothes and accessories.

Residents use the park in the mornings for walking, jogging, and exercising, and later flock the stalls of food vendors located outside of the park. Blue-collar workers employed in the neighborhood purchase their lunch from the same food vendors, and eat in the park in warm afternoons. The shaded areas of the park are used by the men to relax or nap during the afternoons, who often buy tea and snacks from the food vendors in late afternoons. Evenings at the park are very active, as mothers bring their toddlers to the play area, older adults walk and buy tea, juices, or snacks, many middle-aged women come to buy fruits or vegetables and often gather near clothes and accessories, all staying longer hours. A young mother who frequents the park with her toddler stated: "I come here regularly! There's so much to do, especially outside the park. I often grab fruits and vegetables on my way back or glance through the jewelry on the street." The vendors drive the activity generation from late evenings till near midnight, ensuring footfall even after the park closes. Another male older adult explained: "I come here with my (male) friends every day to get fresh air. We gather near this tea stall and chat until we leave. He (pointing at the tea vendor) makes the best tea!" This study observed and mapped such tea and pan (mouthfresheners made from betel leaf and areca) stalls all over the zone. Though they increase activity on the street late at night, they are often associated as a "nuisance" for being male-dominated spaces. 


\section{COGITATIO}

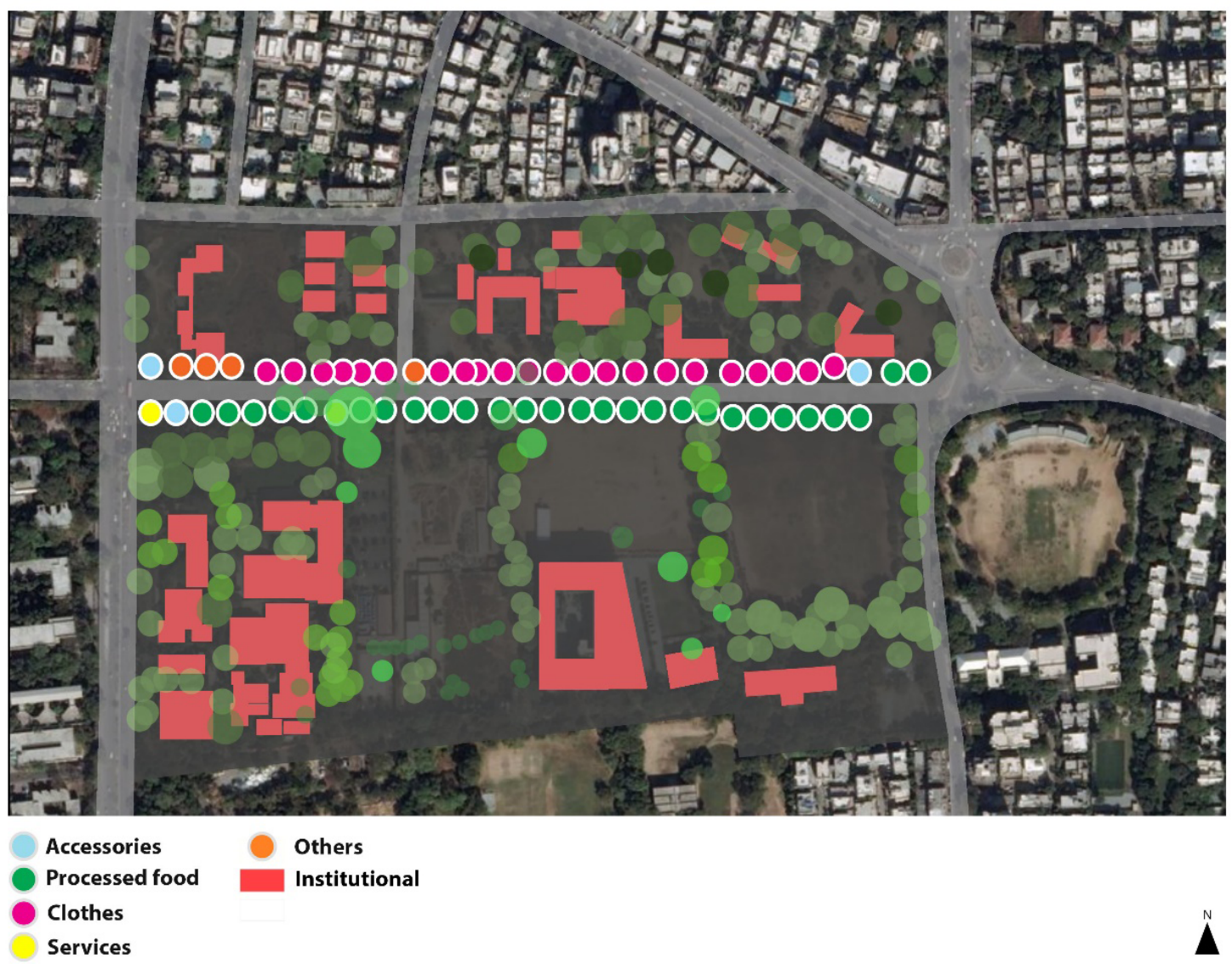

Figure 5. Street market on University streets. Source: Field work.

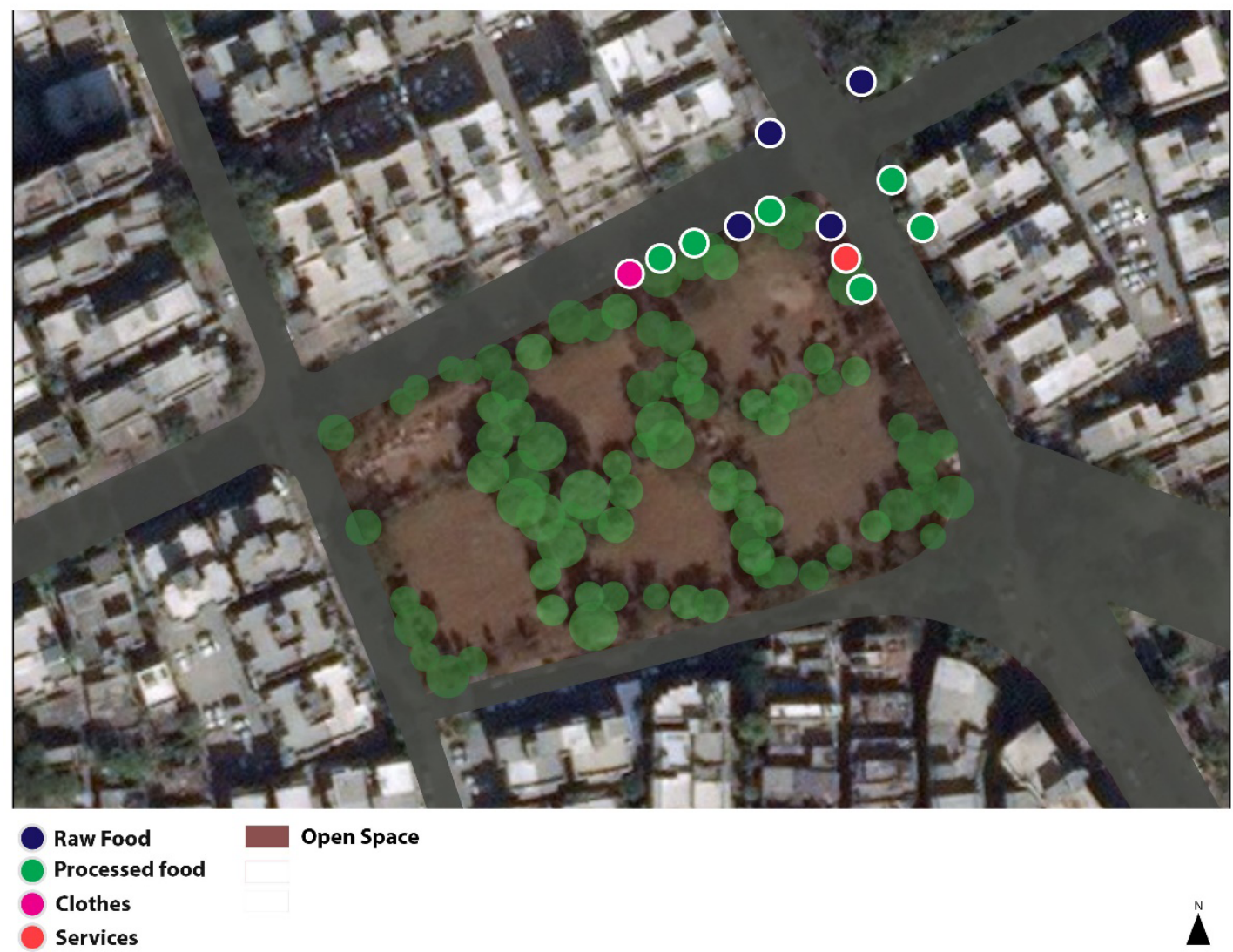

Figure 6. Street market at Law Garden. Source: Field work. 


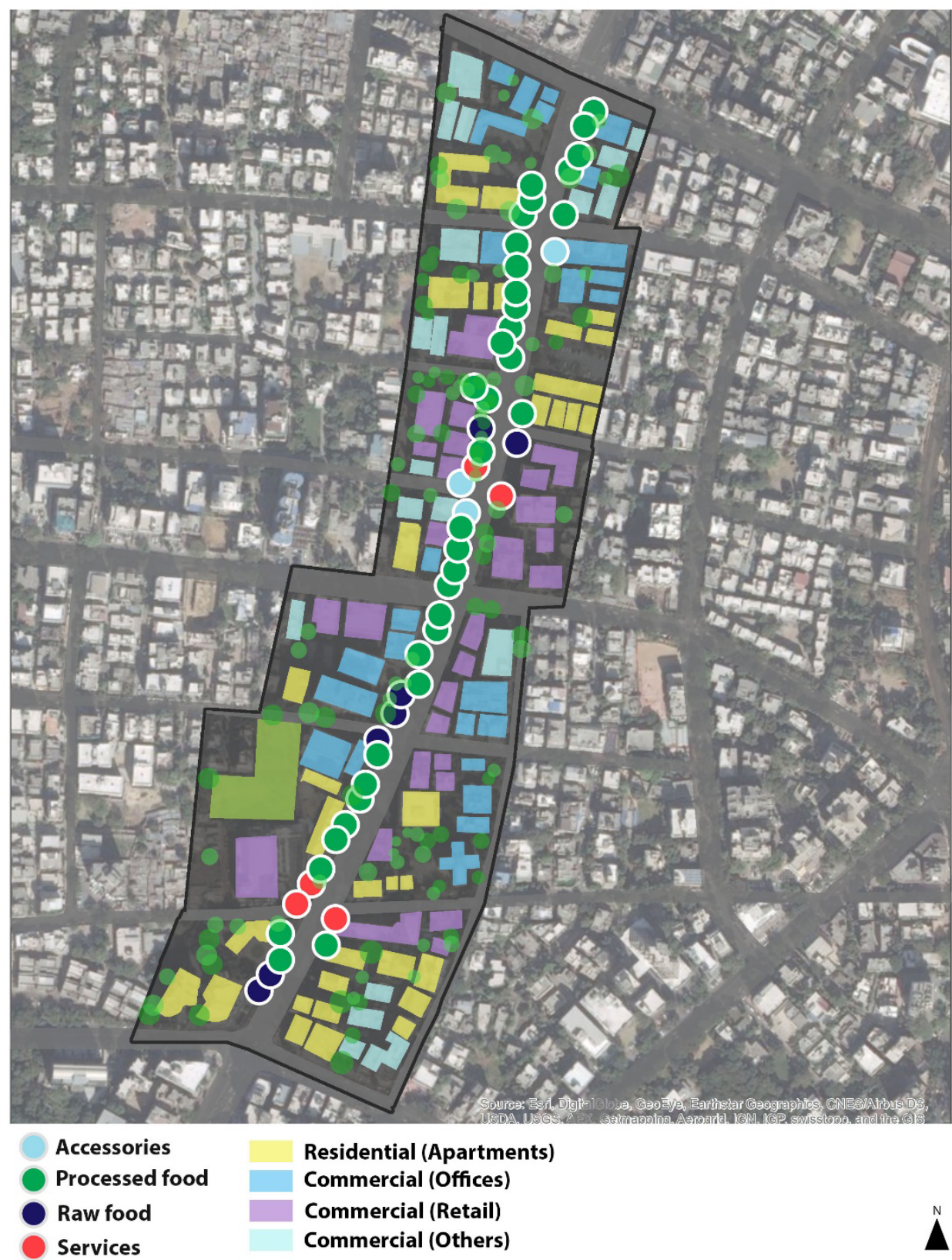

Figure 7. Street market at C.G. Road. Source: Field work.

PPS' Place Diagram Tool indicates how diverse activities can offer greater opportunities to engage with the public space and retain a higher volume of users. Gehl's (2011) and Cullen and Whiteford's (2001) theories emphasize the importance of social capital developed through social interaction in public spaces. Street vendors and the park function in synergy by offering more activities, which retains people from different age and income groups. This fosters a sustained social interaction in and around the space, making it more vibrant.

\subsection{Safety}

Safety has always been a core indicator of a "good" public spaces. There are numerous studies that mea- sure the safety of different user groups based on aspects such as gender, race, age, religion. Many studies also draw attention to shopkeepers' and businesses' perception of safety through the context of streets and street vendors. Some variables of safety include "informal surveillance," activity generation, footfall, and familiarity. To understand the street vendors role in safety, this study examined the case of a residential neighborhood in Sabarmati Ward.

\subsubsection{Sabarmati's Typical Neighborhood}

Sabarmati Ward, known for its Railway Colony government housing, is one of the first residential wards in Western Ahmedabad. The residential area predom- 
inantly has vertical mixed use on both sides of major roads. Over 40 percent of the ward's population lives in slums and squatter settlements. Less than 1 percent of the ward's land is dedicated to "formal" public spaces, all of which are poor quality, heavily polluted with solid waste. As a result, the streets are the community's preferred and possibly the only viable public spaces. There are three major bazaars along the vertically mixed-use streets of the ward.

The neighborhood is comprised predominantly of lower-class and middle-class residents, followed by employees of smaller commercial and institutional set-ups. Local streets constitute a significant component of the street network. Between 35 to 40 percent of street vendors are mobile in nature and provide goods and services for daily use like fruits and vegetables, or collect recyclable items such as old newspapers, tins, cans, or glass bottles. Stationery vendors agglomerate on the intersections of streets that have greater visibility and market potential. Most of these stationery vendors sell processed food like snacks, tea, lemonade, and pan. This case is representative of composition and location trends for mobile vendors throughout West Zone. This study's preliminary assessment indicates that local and collector streets are circulated by 35 and 38 percent respectively of the total population of mobile vendors. Specifically, most mobile vendors are found in predominantly residential neighborhoods where the demand for doorto-door services is the highest.

The mix of mobile and stationary vendors offer diverse experiences of sharing the street with them. Early mornings in the local streets are very busy with "necessary activities" (Gehl, 2011), children traveling to school and adults rushing to their workplace. Mobile vendors are the sole activity generators in the neighborhood from late morning through early evening, keeping the otherwise "dull" and inactive street interesting and safe. During this time, women who buy goods or services from the mobile vendors often find an opportunity to have a short conversation among themselves, extending the necessary activity to "social activities" (Gehl, 2011). A middleclass housewife explained: "My friends (women from other apartment blocks) and I often walk to this crossroad to buy fruits and vegetables. That is the only time we can catch up without taking out dedicated time from our daily schedules!" The mobile vendors slowly disappear by evening, and the stationery vendors on the intersections become major destinations. Children and youth flood the ice-cream and food stalls by evening, women buy fruits and vegetables, and older male adults sip tea at the tea stalls. Men and middle-aged couples are often found by tea or pan stalls during late evenings. These observations further cement the argument that the presence of these vendors generates activity in a relatively "dead" space, extends hours of use and provides informal surveillance, all of which make the neighborhood safer. The rich literature on safety in public spaces indicates that women, children, and older adults feel safer in the presence of familiar vendors and people (Phadke, 2007). Many shopkeepers and smaller businesses admit feeling safer in the presence of vendors when shopkeepers are away for some time, as the vendors "guard the area" and serve as "eyes on the street" (Anjaria, 2006; Jacobs, 2002).

\subsection{Access}

Rapid privatization and liberalization of public spaces have popularized gated green open spaces. Given this context, public spaces that are "accessible to all" are crucial for healthy and equal communities. Despite challenges, public spaces must allow for a range of activity for all users. The following case sheds light on physical manifestation of building activity and equity in a public space in the West Zone of Ahmedabad.

\subsubsection{CEPT Khau Gali aka The Food Market}

Khau Gali, popularly known as CEPT Khau Gali is in Navrangpura Ward, which one of the most affluent wards in the West zone. This ward consists predominantly of high-income residential, and has a large share of institutional, and commercial land-uses, which constitute 50,20 , and 18 percent of all land uses, respectively. Navrangpura also has the highest share of open space, with 7 percent of all land use. However, many of these open spaces are either gated or are underutilized. This ward receives a massive influx of floating population, as thousands of students and young professionals travel there throughout the day, which creates a larger need for a "good" public realm.

This street is located amidst educational institutions and was used only as a thoroughfare historically. The street vendors on this street were previously located on the perpendicular arterial street, called 120 Feet Ring Road. That arterial street was adopted as a "model road" by the local authority in the 1990s (Mahadevia et al., 2014). Their vision of creating a model road for the state only involved automobiles however. This resulted in truncated sidewalks and the large-scale displacement of street vendors, making 120 Foot Ring Road exclusive for vehicular traffic. After multiple eviction drives by local authorities, the vendors finally returned to two perpendicular streets, CEPT Khau Gali and LD College Khau Gali, which are both collector streets. The literature on "natural markets" suggests that vendors prefer to locate on streets with maximum footfall and activities, i.e. subarterial streets. But empirical evidence from surveying 4,000 street vendors in West Zone highlights that street vendors are more likely to be in a street market or a market inside a plot than alone. The greatest number of street markets are located along collector streets, which contain 38 percent of street markets. This is followed by local streets with 35 percent of street markets, and subarterial and arterial streets with 17 and 8 percent, respectively. Thus, street vendors are pushed away from their 
natural markets on the sub-arterial and arterial streets, and forced to locate in the collector and local streets.

CEPT's Khau Gali is active throughout the day from early mornings until late nights. Food vendors line on one side of the street throughout the day, while vendors selling new clothes and accessories start clustering on the other side of the street beginning in early evenings. Food vendors are busy throughout the day, especially due to students from adjoining institutes flooding their stalls. Clothes and accessories vendors transform the street into a city-level market in the evenings. There are hundreds of people walking, eating, chatting, sitting, and shopping in evenings. Students working till late night at CEPT University purchase snacks, tea, and coffee from the food vendors, which keeps the street active in late hours. A nearby resident said "this place looked nothing like this a few decades ago! It was just any other road people zoom through, but now you can pause and enjoy the street!" A major criticism consistently facing this market is an increase in congestion due to haphazard vehicle parking by the clientele historically. Despite this conflict, the high service provision by street vendors has protected them from evictions in the past.

Street vendors make the otherwise thoroughfare street more multifunctional by generating opportunities for commercial, recreational, leisure, and mobilityrelated activities. They extend the hours of engagement and add color to deserted sidewalks defined by long, blank institutional walls, which makes it safer for people of all gender, age, and income. Thus, this study argues that the presence of street vending makes this street "accessible to all" (Sasidharan \& Prosperi, 2012).

\subsection{Infrastructure}

Despite being a traditional occupation, street vending is constantly criminalized in the modern world. In instances when the street vendors are decriminalized and supported by the government, markets have flourished into more attractive spaces. State support and sponsorship is essential beyond legalizing the occupation. This can be done by providing space and basic infrastructure such as public toilets, access to drinking water, access to transportation, waste management, and electricity.

\subsubsection{Law Garden}

Situated in the Navrangpura Ward, Law Garden is one of the most celebrated public spaces in Ahmedabad. As mentioned previously, Navrangpura Ward has a large proportion of open space, with Law Garden being the largest area. There are two popular city-level street markets located in Law Garden: the handicrafts market and the food market.

Law Garden is located at the center of a bustling neighborhood, and surrounded by commercial, institutional and mixed-use developments. Traffic congestion and curbed vehicular mobility motivated the local au- thority to evict street vendors in Law Garden. The street market initially emerged as a seasonal market due primarily to the Garden's popularity, but soon became closely tied to the neighborhood's and city's image. Thus, the community constantly protested the eviction, and initiated several public dialogues to return the street markets. The community and the city abandoned Law Garden, which made it suitable for illicit activities. Many grassroots organizations such SEWA, local urbanists, and passionate citizens negotiated with the local authority to restore the street markets. This gave the state its first unique "organized" street market. The street around Law Garden was redesigned to build sheds as spaces for vendors. This included wide sidewalks, electricity provision, waste management, and access to the garden's water fountain and public toilets. All vendors were also provided a vending license. The newly improved Law Garden exponentially increased footfall and revenue generation.

Current mornings in Law Garden are busy with residents walking and exercising in the garden. After this, they move to the food market to purchase tea and snacks, which extends the public realm from the park. Youth from adjoining schools and colleges flood the garden and markets during the afternoons. The evenings are the busiest time period, with various users utilizing the area through activities including playing, socializing, shopping, eating or sight-seeing. A young student who frequents the place with his friends said, "these bazaars are so well designed and maintained......It feels like a part of the park. I regularly come here to hang-out with my friends and eat my favorite pav-bhaji (Indian street food)!" A middle-aged visitor from another city said, "I've never been to bazaars like these. It's clean, bright, busy, colorful and so comfortable to be in!"

Many studies highlight how "organized" street vending spaces or zones with adequate infrastructure improve the user experience and provide workplace security and comfort to street vendors. Findings from this study's preliminary assessment also emphasized this same conclusion. Most street vendors prefer locating in a spot with tree shade or canopy cover and sidewalks. Unfortunately, 38 percent of collector streets and 55 of local streets in the zone have no sidewalks, and only 30 percent of collector and local streets have any canopy cover. This exposes most street vendors to the risk from vehicular traffic and harsh climate conditions.

Law Garden has been a focal point of legislative conflict over street space since the 1950s (TNN, 2018a). Despite several mechanisms, local policies, and governance systems formalizing street vending along both sides of Law Garden, the ULB continues to harass, evict, and displace street vendors in the name of abating parking issues, congestion, and menace. In Ahmedabad's latest eviction drive in 2018, the ULB and the police demolished formalized structures and evicted all licensed street vendors, citing street vendors 'encroach' upon street space used for traffic. This incidence highlights that legislation and local administration reforms do not guarantee the 
preservation of street vending, and a change in narrative is greatly needed.

\subsection{Equity}

Equity is the basic principle to term any space as "public". Per previously discussed literature, good public spaces dilute all socio-economic barriers, and foster social cohesion. All five cases strongly demonstrate the contribution of street vending in diluting socio-economic and generational divides, promoting multipurpose and multimodal nature of streets, and making streets more equitable. This case presents an interesting take on equity through its unique interplay between the formal and informal sector.

\subsubsection{C.G. Road's Commercial Stretch}

Named after the business tycoon Chimanlal Girdhalal in the 1960s, C.G. Road is a prime commercial axis of Ahmedabad. Formerly planned as a residential neighborhood, C.G. Road now thrives with a wide range of commercial activities, including offices, retail shops, malls, restaurants, and cafes. It is surrounded by high-end residential and vertically mixed-use development. Once known as the city's favorite street for celebrating various festivals like Diwali and Christmas, the street is now dominated by motorized traffic. Its popularity and significance put it at the center of the city's placemaking initiatives. "Happy Streets" or "RaahGiri" (translated as a sweet rebellion to reclaim streets) is the State's first successful movement to reclaim street for all and began on C.G. Road.

As mentioned above, C.G. Road's is predominately commercial, with around 90 percent of the area's land use. It is surrounded by a rich network of streets, many of which are sub-arterial. Over 95 percent of street vendors are stationery, and around 60 percent of them are located on major intersections. Another 25 to 35 percent are located near malls and offices, and less than 5 percent are mobile vendors spotted close to mixed-use developments. 80 percent of vendors sell processed food, while 15 percent provide fruits and vegetables, services like shoe or bike repair, or sell accessories.

Vendors arrive on C.G. Road by late mornings. Soon most white-collar workers flood the food vending stalls for tea, lemonade, juices, and snacks. At noon, many blue-collar workers purchase affordable lunch from the same vendors and eat under the shade provided by trees on the street. From late afternoons to evenings, food vendors located close to the offices serve tea and snacks to the workers inside their office buildings. This is a rare situation where street vendors are valued and openly welcomed into formal work premises. People often stop by the vendors on their way back from offices and malls during evenings, creating a larger public sphere on an otherwise automobile dominated street. It is shared by a diverse group including street vendors, blue-collar work- ers, white-collar workers, and students from neighboring wards. Thus, the contested space becomes more equitable due to the presence of street vending (Jain \& Moraglio, 2014).

CG Road's prime location, demand for space, tricky parking management, and dense population require a design and management update regularly. After 23 years since the last redevelopment, AMC's envisions to make CG Road the State's first "Smart Model Road" (Ahmedabad Mirror, 2018). This vision includes parking for 2 and 4 wheelers, bike lanes, green canopy, benches, paved blocks for pedestrians, CCTV cameras, WIFI-based LED street lighting monitoring system, Electric Vehicle charging stations, integrated commercial display boards, and speakers for announcements (TNN, 2018b). There is no provision for street vendors, rickshaw stops, nor other informal workers. The city's vision for redeveloping a key street, thriving on urban informality, again has no space for the urban poor.

\section{Conclusion and Recommendations}

Street vendors are a significant component of both the informal economy and public spaces. They are selfemployed, support other small businesses, contribute to the city's revenue generation, and help reduce urban food insecurity. Although most governments across the globe recognize their importance, they are often misconstrued as 'illegal', 'flagbearers of chaos', 'nuisances' and 'tax-evaders'. Furthermore, they are perceived as 'encroaching' the city's prime land and contributing as a source of congestion and menace. There are a significant number of empirical studies highlighting how street vendors often pay extortion money, protection money, or provide free snacks, goods or services to various government bodies such as the ULB, the Police, the traffic police, the public health department for protection. Street vendors are central to the debate of space, especially in densely populated cities where land is a rare commodity. They constantly face the hardships of evictions, displacement, and confiscation of goods, especially during urban infrastructure and renewal projects. In states where street vending is not regulated, food vendors pose a public health challenge. Thus, formalizing street vending can address these concerns effectively.

The case of Ahmedabad highlights some interesting location patterns in relation to surrounding landuse, street, and amenities. Stationary street vendors are more likely to be in a street market or a market than alone. 38 percent of street markets are located along with collector streets, while 35 percent are along local streets, followed by sub-arterial and arterial streets with 17 and 8 percent, respectively. A rich literature on street vending in Ahmedabad depicts the eviction and displacement of street markets from "important" sub-arterial and arterial streets, prioritized by AMC for vehicular circulation, to local and collector streets, which further reinforces this finding. Mobile street vendors are more likely 
to be found in predominantly residential areas where the demand for door-to-door services is greatest. Hence, collector and local streets contain 38 and 35 percent of mobile vendors, respectively. An overwhelming majority of street vendors prefer locating in spots with canopy cover and sidewalks. Unfortunately, 38 percent of collector streets and 55 percent of local streets in the West Zone have no sidewalks; and 70 percent of collector and local streets lack any canopy cover. This exposes street vendors to risks from oncoming vehicular traffic and harsh climate conditions.

The five case study pockets and perception study provide a fresh perspective to ongoing discussions on public spaces and street vending. Activities drive people to visit the place. The purpose of using the space ranged from necessary, to optional, to recreational activities (Gehl, 2011). These spaces were often a part of people's daily routines, but also constituted an opportunity to explore the city's amenities. The presence of street vendors enhances the experience of a space. The frequency of usage is independent of street vending but is closely tied to the type of activities offered. Daily activities such as buying groceries from neighborhood street vendors are an example of necessary activities, while, buying handicrafts from Law Garden can be a recreational activity. People enjoy the space in varied ways: in groups of friends or family, especially for activities like walking or jogging in the local park, shopping and eating at street markets or individually. Examples of individual interactions include a blue-collar worker eating lunch at a food stall, or a mother dropping off her child to school and buying fresh vegetables from the mobile street vendor on her return. Though the users in all 5 cases largely perceive the space in positive light, they often mentioned infrastructure related issues, such as parking, waste management, and congestion. These problems are true for most areas in the city with similar land use and density. However, their perception of the street vendors predominantly emphasizes the contribution of street vending in making the space more vibrant, the streets safer and their lives more convenient. Most users highlighted that street vendors allow them to reduce the number of trips by consolidating multiple purposes into one trip.

In conclusion, street vendors contribute to making streets truly "public." They act as a transition between the street and its adjoining properties by extending the public realm. Streets with dominant vehicular movement encourage greater pedestrian use due to street vending. Street vendors act as "eyes on the streets" and attract greater numbers of people. They foster platforms where people from different income groups, age groups, communities, and genders can interact actively or passively. They reclaim the streets and make them multipurpose in nature. A change in the narrative of the role of street vendors in public spaces and the larger urban system will help implement reformative legislation, local policies, and governance mechanisms.

\subsection{Recommendations}

ULBs and other local authorities should recognize the contributions of street vendors and support street vending to protect vendors from exploitation, harassment, and evictions. Incorporating an equitable urban development model that includes the city's urban poor with a focus on the working poor is crucial for building sustainable and resilient urban systems. Surveys on the economic contribution of street vending can be a significant motivator for preserving and promoting street vending in urban areas. A thorough survey of all street vendors in Ahmedabad that includes socio-demographic information, their locations, and their specific needs will aid the ULB in providing better services for vendors. Identifying all "natural markets" and striving to preserve them is crucial for effective implementation of the Street Vendors Act of 2014. Thus, a holistic survey identifying all the "natural markets" and all street vendors is key for an equitable integration of vendors.

All street vendors must be provided with licenses (vending and food handling licenses) and dedicated spaces close to their respective "natural market." The licensing process should be expedited, and current vendors must be given a priority over new vendors. The space allocation must respond to the needs, scale, and context of the community. All street vendors must have access to basic services such as potable water, clean toilets, proper lighting, and shade for protection from the elements. After identifying specific needs in markets, space and additional facilities should be made available to vendors. The local authorities should ensure the safety of street vendors, especially those who are more vulnerable ones such as women, "lower" caste vendors, and below poverty line vendors.

To ensure an equitable solution for any space conflicts, a fair representation of all stakeholders including residents, shopkeepers, business associations, street vendors, advocacy groups, etc. in the Town Vending Committee is essential. Furthermore, with the help of non-profits and advocacy groups, ULBs must aim to organize street vendors to form committees that can ensure smooth functioning and governance of street markets. With a focus on parking management and mobility, ULBs must collaborate with urbanists, design professionals, and enthusiastic community members to innovate space management solutions, along with proper waste management mechanisms.

\section{Acknowledgments}

We thank Mr. Armeen Neshat for editing the article. We are grateful to Mr. Mahroof, CEPT University and Ms. Bhuvana, CEPT University for inputs. We are also thankful to Vaidehi Gohil and Anjali Chaudhary from CEPT B.Plan 2016 cohort for Round 1 of data collection process. 


\section{Conflict of Interests}

The authors declare no conflict of interests.

\section{References}

Ahmedabad Mirror. (2018, October 26). Post-Diwali, CG Road to get Rs 30-cr facelift. Retrieved from https:// ahmedabadmirror.indiatimes.com/ahmedabad/ civic/post-diwali-c-g-road-to-get-rs-30-cr-facelift/ articleshow/66369028.cms

Anjaria, J. S. (2006). Street hawkers and public space in Mumbai. Economic and Political Weekly, 41(21), 2140-2146.

Benítez, M., Grice, J., \& Harvey, J. (2018). Working in public space: A manual for street vendors. Retrieved from http://www.wiego.org/sites/default/ files/resources/files/Workinginpublicspace.pdf

Bhaskar, B. (2019, April 9). Whither the Gujarat model? The Hindu. Retrieved from https://www. thehindubusinessline.com/opinion/columns/fromthe-viewsroom/whither-the-gujarat-model/ article26784596.ece

Brower, S. (1996). Good neighborhoods. Westport, CT: Praeger.

Carr, S. (1992). Public space. Cambridge and New York, NY: Cambridge University Press.

Census. (2011). Primary census abstracts. New Delhi: Office of the Registrar General \& Census Commissioner, India.

Cullen, M., \& Whiteford, H. (2001). The interrelations of social capital with health and mental health. Canberra: Commonwealth of Australia.

Desai, R. (2014). Municipal politics, court sympathy and housing rights: A post-mortem of displacement and resettlement under the Sabarmati Riverfront project (Working Paper, No. 23). Ahmedabad: Centre for Urban Equity, CEPT University.

Gehl, J. (2011). Life between buildings: Using public space. Washington, DC: Island Press.

Herrera, J., Kuépié, M., Nordman, C. J., Oudin, X., \& Roubaud, F. (2012). Informal sector and informal employment: Overview of data for 11 cities in 10 developing countries. Cambridge: WIEGO.

Jacobs, J. (2002). The death and life of great American cities. New York, NY: Random House.

Jain, A., \& Moraglio, M. (2014). Struggling for the use of urban streets: Preliminary (historical) comparison between European and Indian cities. International Journal of the Commons, 8(2), 513-530.

John, P., \& Sharma, S. (2018, August 9). Rights of street vendors robbed in Gujarat. Times of India. Retrieved from https://timesofindia.indiatimes.com/city/ ahmedabad/rights-of-street-vendors-robbed-ingujarat/articleshow/65345313.cms

Joshi, K. (2018). 'Conditional' citizens? Hawkers in the streets (and the courts) of contemporary India. Articulo: Journal of Urban Research. http://dx.doi.org/ 10.4000/articulo.3383

Kim, S. (2015). Public spaces: Not a "nice to have" but a basic need for cities. Retrieved from http:// blogs.worldbank.org/endpovertyinsouthasia/publicspaces-not-nice-have-basic-need-cities

Mahadevia, D., \& Vyas, S. (2012). Law, Regulations and Rights of Street Vendors: Ahmedabad. Ahmedabad: Centre for Urban Equity.

Mahadevia, D., Bhatia, N., Abhilasha, N., \& Patel, S. (2017). Improving women's safety on Sabarmati Riverfront. Ahmedabad: Centre for Urban Equity.

Mahadevia, D., Brown, A., Lyons, M., Vyas, S., Jajoo, K., \& Mishra, A. (2013). Street Vendors in Ahmedabad: Status, Contribution and Challenges. Ahmedabad: Centre for Urban Equity.

Mahadevia, D., Desai, R., \& Vyas, S. (2014). City profile: Ahmedabad. Ahmedabad: Centre for Urban Equity.

Mahadevia, D., Mishra, A., Joseph, Y., \& Das, A. (2016). Street vending in Guwahati: Experiences of conflict. Ahmedabad: Centre for Urban Equity.

Mahadevia, D., Vyas, S., \& Mishra, A. (2014). Informal economy monitoring study: Street vendors in Ahmedabad, India. Manchester: WIEGO.

Mboup, G., Warah, R., \& United Nations Human Settlements Programme. (2013). Streets as public spaces and drivers of urban prosperity. Nairobi: United Nations Human Settlements Programme.

Mehta, V. (2007). A toolkit for performance measures of public space. Paper presented at the 43rd ISOCARP Congress, Antwerp, Belgium.

New Urbanism. (n.d.). Retrieved from http://www. newurbanism.org/bookstore/links.html

Phadke, S. (2007). Dangerous liaisons. Women and men: Risk and reputation in Mumbai. Economic and Political Weekly, 42(17), 1510-1518.

PPS. (n.d.). What makes a successful place? Retrieved from https://www.pps.org/article/grplacefeat

Ray, C. (2010). Livelihoods for the urban poor: A case study of UMEED Programme in Ahmedabad. Ahmedabad: Centre for Urban Equity.

Ray, C. N., \& Mishra, A. (2011). Vendors and informal sector, a case-study of street vendors of Surat City. Ahmedabad: Centre for Urban Equity.

Roever, S. (2014). Informal economy monitoring study sector report: Street vendors. Cambridge: WIEGO.

Roever, S., \& Skinner, C. (2016). Street vendors and cities. Environment and Urbanization, 28(2), 359-374. https://doi.org/10.1177/0956247816653898

Salès, L. (2018). The Street Vendors Act and the right to public space in Mumbai. Articulo: Journal of Urban Research. Retrieved from http://journals. openedition.org/articulo/3631

Sasidharan, P., \& Prosperi, D. (2012). Dichotomy of urban public spaces. Paper presented at the 48th ISOCARP Congress, Antwerp, Belgium.

Shah, P. (2009). Seeing the city. Ahmedabad: Landscape Environment Advancement Foundation. Retrieved from http://www.leaf-india.org/assets/download/ 
publications/seeing_the_city.pdf

Skinner, C., Orleans, S. R., \& Harvey, J. (2018). Supporting informal livelihoods in public space: A toolkit for local authorities. Brussels and Manchester: WIEGO.

Statista. (2018). India: Total number of vehicles in Ahmedabad 2016. Statista. Retrieved from https://www.statista.com/statistics/665754/totalnumber-of-vehicles-in-ahmedabad-india

Thalis, P., \& Cantrill, P. J. (n.d.). Public Sydney: Drawing the city. Retrieved from http://www.hillthalis.com. au/index.php?id=114

TNN. (2018a, August 1). AMC's about-turns on Khau
Gali. Times of India. Retrieved from https://timesof india.indiatimes.com/city/ahmedabad/amcs-aboutturns-on-khau-gali/articleshow/65235303.cms

TNN. (2018b, October 25). Street light: Ahmedabad: CG Road to be redeveloped up to Parimal Crossroads. Times of India. Retrieved from https://timesofindia. indiatimes.com/city/ahmedabad/cg-road-to-beredeveloped-up-to-parimal-crossroads/articleshow/ $66371079 . \mathrm{cms}$

Zukin, S. (1995). Culture of cities. Oxford: Blackwell Publishers.

\section{About the Authors}

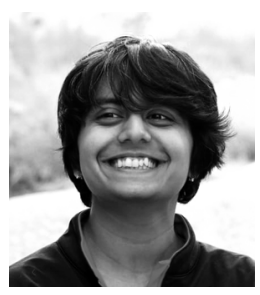

Prithvi Deore serves an Assistant Regional Planner at Southern California Association of Governments (SCAG). She received her Master's of Planning from USC Sol Price School for Public Policy in 2018 and her Bachelor's in Planning from CEPT Univeristy at Ahmedabad, India in 2016. Prior to joining SCAG, she worked as a Research Assistant at CEPT's Center for Urban Equity (CUE). Prithvi is passionate about researching urban inequities and transportation challenges.

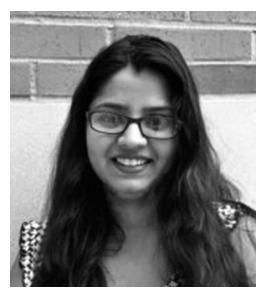

Saumya Lathia is a Master's student of Planning at USCSol Price School for Public Policy. She received her Bachelor's in Planning from CEPT University at Ahmedabad, India, in 2016. Saumya served as a Research Assistant at Sol Price Centre for Social Innovation and CEPT's Centre for Urban Equity. Her research interests include urban and regional inequities, informal economy and housing, urban sustainability, and social justice. Saumya received the Best Gender Thesis Award for her undergrad thesis on 'Gender and Public Spaces: A Case Study of Sabarmati Riverfront' in 2017. 